\title{
1950 Summary of Christmas Bird Count
}

By Maurice G. Street, Nipawin

With three less localities reported from, than last year, the total number of species recorded, 24 , is the same. However the to tal individial birds counted is somewhat more on the average. Weather conditions were much more favorable than a year ago. The average depth of snow reported about 6 inches, with the temperature just below the zero mark.

Two new species, unrecorded in the previous 8 annual counts, bring the total species, ( or sub-species recognizable in the field ) up to 62 . The American Crow, reported by Doug. Gilroy and T. M. Beveridge, was seen in the valley of Boggy Creek, 15 to 20 miles north west of Regina, and a Yellow-shafted. Flicker reported from Skull Creek by Steve A. Mann, are new to the list of birds reported in mid-winter.

Sharp-tail ed Grouse, Ruffed Grouse and particularly Hungarian Partridge appear to be quite plentiful. Snowy Owls are reported from 5 localities, their numbers appear normal for the average winter. The number of American Magpies reported are rather less than usual, evidence of general downward trend over the past two years. For the first time, not a single Evening Grosbeak was reported, while the Pine Grosbeak is reported in the usual numbers.

For the second straight year, Cedar Waxwings were noted at Yorkton, this time 52 were counted. It would be interesting to learn what particular food supply is present in that locality that is proving so attractive to these normally summer visitors.

BROADVIEW: Dec. 26, 1950: By car, 108 mil es via Highways $22,10,35$ and 1 Abernethy to Broadview. Sharp-tailed Grouse, 6; Hungarian Partridge, 6; Snowy Owl, 1; Am. Magpie, 8; Common Redpoll, 150 ( est ); Snow Buntings, two large flocks.

Mr. \& Mrs. Charles I. Thacker.

BREDIN SIDING: Dec. 29, 1950. Valley of Boggy Creek, 15 to 2 miles northwest of Regina. Affield $11.30 \mathrm{a} . \mathrm{m}$. to 4 p.m. Hungarian Partridge, 12 ; Downy Woodp ecker, 1; Am. Magp ie, 20; Am. Crow, 1; Black-capped Chickadee, 4; Bo hemian Waxwing, 9; Starling, 2; English Sparrow, 50 ( est. ); Blackbird (Brewer's?), 2; Common Redpoll, 11.

Doug . Gillroy and T. M. Beveridge.

BL ADWORTH: Dec. 26, 1950. Walk of $4^{1 / 2}$ mil es. 9. 40 a.m. to 11.40 a.m. Sharp tailed Grouse, 11; Hungarian Partridge, 71; Snowy Owl, 1; Am. Magpie, 2, English Sparrow, 10; Snow Bunting, 1. Lawrence Beckie.

HAWARDEN: Dec. 26, 1950. Prairie with no trees except for groves around farms. Observations from farm yard, 9 a.m. to 3.30 p.m. Sharp-tail ed Grouse, 9; Hungarian Dartridge, 13; English Sparrow, 100 ( est. ); Brewer Blackbirds 2.

Noble $\mathrm{Kvinge}$ and $\mathrm{H}$ arold $\mathrm{Kvinge.}$

LANG: Dec. 25, 1950 . Wialk of 5 miles. Sharp-tailed Grouse, 8; Hungarian Partrirge, 7; Snowy Owl, 1; Snow Bunting, hundreds in several large flocks.

Len. Dreger.
NAIC AM: Jan. 7, 1951. A walk of 4 miles through fields and wood. Downy Woodpecker, 1; Am. Magpie 1; Blackc apped Chickadee, 5; Pine Gros beak, 4. W. Yanchinski.

NIP AWIN: Dec. 31, 1950.40 mile drive by car along Flin Flon Highway. 11.00 a.m. to 4.00 p.m. Pileated Wo odpeck er, 1; Hairy Woodpecker, 1; Canada Jay, 2; Blue Jay, 1; Am. Magpie. 2; Raven, 2 ; Black-capped Chickadee, 2; Bohemian Waxwing, 25; English Sparrow, 20 (est. ); Pine Gros beak, 5; Common Redpoll, 92 ( est.) Snow Bunting, 3110 ( est. ).

Billy Matthews, Walter Matthews and M. G. Street.

REGINA: Dec. 26, 1950, 30 Block Argyle St. via Hill Ave. and Bldg. Grounds to Broad Street bridge and back on 20 th A ve. 2.00 a.m. to 4 . a.m. Redbreasted Nuthatch, 2; English Sparrow, a few seen; Pine Grosbeak, 1 seen, others heard.

E. Barker

SHEHO: Dec. 30, 1950. Census taken while going about chores around yard, straw stacks and fields. Quffed Grouse 4; Sharp-tailed Grouse, 16; Hungarian Partridge, 8; Great Horned Owl, 2; Hairy Woodpecker, 1; Downy Woodpecker, 1; Am. Magpie, 2; Black-capped Chickadee, 2; Pine Grosbeak, 6; Snow Bunting, 50 ( est. ).

Wm. Niven. 
SKULL CREEK: Christmas Week, 1950 . Birds noted while going about daily work on ranch. Mallard, 1; Golden Eag: le, 1; Prairie Falc on, 1; Ruffed Grouse, 1; Prairie Chick en (Sharp tailed?) 16; Hungarian Partridge, 11; Ring-necked Pheasant, 1; Great horned Owl, 2; Snowy Owl, 2; Yellow-shafted Flicker, 1; Hairy Woodpecker, 2; Horned Lark, 21; Am. Magpie, 22; Black-capped Chickadee, 6; English Sparrow, 33; P ine Gros beak, 15; Common Redpoll, 200 to $300 ;$ Tree sparrow, 12; Snow Bunting, 16.

Steve A. Mann.

WALL WORT: Dec. 27, 1950. 3 mile walk north on Highway 35 and 4 miles north on side road, and about the home farm yard. Sharp-tailed Grouse, 7; Canada Jay, 3; Raven, 2; Hairy Wood- peck er, 2; Downy Woodpecker, 1; Blackcapped Chickadee, 6; Pine Grosbeak, 5. J. Turnquist.

YORKTON: Dec. $26,1950.9$ a.m. to $3.30 \mathrm{p.m}$. 12 obs ervers in 4 parties. Total party hours, $6^{2} / 2$ ( 3 on foot, $3 \frac{1}{2}$ by car); total party miles, 34 ( 3 on foot, 31 by car). Great Horned Owl, 1; Snowy Owl, 2; Downy Woodp ecker, 2; Bl ue Jay, 2; Am. Magpie, 1; Bl ack-capped Chickadee, 4; Cedar Waxwing, 52; English Sparrow, 54; Common Redpoll, 5; Snow Bunting, 518 .

Mary Belcher, Jerry Bulitz, Brother Clarence, Lionel Coleman, Ronald Coleman, Glen Dawes, C. Stuart Houston Dr. C. J. Houston, Dr. S. C. Houston, Cliff Shaw, Jeff Smith, Brother Vincent. ( Members of Yorkton Natural History Society ).

\title{
A Bird Count Suggestion
}

\author{
Marion Nixon, Wauchope
}

I have a suggestion to make that has crystallized over a period of years. Would it not give a truer picture of birds present if a longer period than one day were taken into consideration for the bird count ... say all Christmas week, or even the last fortnight of the year .. but the number reported being the largest number of any one species, seen on one dây during that time.

It is, of course feasible to make a quite comprehensive survey if a club goes out in separate parties, over different areas, to cover a territory in one day. But for the average farmer reporting, this is not a logical count. His bird watching is done incidentally, from a straw rack or on the road to town and over a period of time he sees more birds, of more species, than on any particular day. The gypsy migrants come and go, and even the ma gpies appear in larger congregations if there is offal about.

I have noticed a tendency towards this kind of report in some of your final analyses of winter bird populations, but I believe if you made my suggestion a rule, you would get population re ports on all the species rather than just remarks regarding rare appearances.

\section{Our Pet Oriole}

GERALD BRITTON, (Age 11), Homefield, Sask.

One day last spring a baby oriole fell out of its nest and couldn't get back, as it was not strong enough to do more than flutter around. We were going to put it back into the nest but it wa.s raining and every thing was soaking wot so we decided to keep it until the weather cleared'up. When we went back the old orioles had gone. We realized then that if we did put it back it would have no one to feed it.
It grew up, and became a real pet. We fed it bread-crumbs and water, but it soon learned to help its elf to the jam Whenever we went to the doorstep it would come and land on our heads. Before long it began to visit the neighbors. It stayed there for about a month. Then one day it disappeared. Perhaps it was killed by a cat, but we still hope that it flew south with all the other orioles. 